\title{
Fear of the Formal
}

du Gay, Paul; Lopdrup-Hjorth, Thomas

\author{
Document Version \\ Accepted author manuscript
}

Published in:

European Journal of Cultural and Political Sociology

DOI:

10.1080/23254823.2016.1160658

Publication date:

2016

License

Unspecified

Citation for published version (APA):

du Gay, P., \& Lopdrup-Hjorth, T. (2016). Fear of the Formal. European Journal of Cultural and Political Sociology, 3(1), 6-40. https://doi.org/10.1080/23254823.2016.1160658

Link to publication in CBS Research Portal

\section{General rights}

Copyright and moral rights for the publications made accessible in the public portal are retained by the authors and/or other copyright owners and it is a condition of accessing publications that users recognise and abide by the legal requirements associated with these rights.

Take down policy

If you believe that this document breaches copyright please contact us (research.lib@cbs.dk) providing details, and we will remove access to the work immediately and investigate your claim. 


\title{
Fear of the Formal
}

\section{Paul du Gay and Thomas Lopdrup-Hjorth}

\author{
Journal article (Post print version)
}

Cite: Fear of the Formal. / du Gay, Paul; Lopdrup-Hjorth, Thomas. In: European Journal of Cultural and Political Sociology, Vol. 3, No. 1, 2016, p. 6-40.

This is an Accepted Manuscript of an article published by Taylor \& Francis in

European Journal of Cultural and Political Sociology on 21/04/2016, available online:

http://www.tandfonline.com/10.1080/23254823.2016.1160658

Uploaded to Research@CBS: September 2016 


\title{
FEAR OF THE FORMAL
}

Paul du Gay \& Thomas Lopdrup-Hjorth

\begin{abstract}
Contemporary ideals of organizing increasingly refer to the spontaneous and informal rather than to formal organization. Formality, it is said, is not merely inefficient and a hindrance to organizational creativity and innovation, it is also dangerous and repressive. This critique of formal organization shows up across otherwise largely incompatible traditions of thought, where it has acquired a hitherto unprecedented status. In this paper, we explore this 'fear of the formal' indicating parts of its genealogy and its contemporary manifestations. At the same time, we seek to indicate the continuing constitutive significance of formality and formalization. Rather than residing with formality, as many critics argue, contemporary organizational problems can be traced to the operationalization of the assumption that formality is a fraud that should be dispensed with.
\end{abstract}

\section{Key words}

Formal organization, history, critique, organization theory

"If our civilization breaks down, as it well may, it will be primarily a breakdown in the administrative area. If we can make a real contribution toward preventing such a breakdown, I believe this contribution will be in the administrative area."

(Donham, quoted in Khurana, 2010, p. 189)

\section{INTRODUCTION}

Over recent decades, 'formal' organizations have come in for severe criticism. From the private to the public sector, and across a whole spectrum of actors spanning practitioners as well as academics, formal organization is viewed with increasing doubt and skepticism. In a "Schumpetarian world" (Teece et al., 1997: 509) of dynamic competition and incessant reform, formal organization appears increasingly anachronistic. Indeed, formal organization, and its closely related semantic twin, bureaucracy, are not only represented as ill suited to the realities of the contemporary organizational world, but as a key source from which organizational dysfunctions themselves emerge. 
For that very reason, critics, reformers, and management gurus alike have urged public and private sector organizations to break out of the stifling straightjacket of formality, to dispense with bureaucracy, and to tear down hierarchies. For instance, under the headline 'Gov 2.0' the function of government is 'reimagined' as a platform around which creative citizens collaborate (O’Reilly, 2009). Similarly, adopting a whole new mindset where an organization-centric view of the world is replaced by a more democratic, co-creative, ecosystem-approach is also imagined as an appropriate way of dispensing with costly hierarchies and rigid formalities (Prahalad and Ramaswamy, 2004a, 2004b). Alternatively, the negativites associated with formal organization are to be countered by creating carnivalesque 'bonkers organizations' with 'zanies in charge' (Peters, 1992), by 'firing all the managers' (Hamel, 2011) or by simply 'organizing without organizations' (Shirky, 2008). Although the solutions proffered are quite diverse, they are nevertheless built around a common narrative: On the one hand, we have the recent past with its rigid organizations, managed through formal structures, and supported by theories and principles coined before the middle of the twentieth century. On the other hand, we have the present or immediate future, producing radical new conditions and challenges that cannot be adequately met by relying upon structures and principles inherited from the past. In our present, it is stated, complexity rules, everything changes and organizational arrangements therefore need to be supple, adaptive and permanently beta.

In such a world, 'formal organization' appears old-fashioned and out of tune with the revolutionary demands of the present. Thus, formal, understood as something done "or made with the forms recognized as ensuring validity" (OED, online), comes to appear as hopelessly outdated, inflexible and restrictive when the world is constantly on the move. For that reason informal and spontaneous modes of organizing have emerged, or better re-emerged, as preferable substitutes, because they, in contrast to the formal, allegedly, allow for creativity, inventiveness, flexibility, speed, and freedom. Whereas 'informal' signals something "[n]ot done or made according to a recognized or prescribed form”; something "not observing established procedures or rules”; 'spontaneous,' in a closely related manner, signals actions “[a]rising or proceeding entirely from natural impulse, without any external stimulus or constraint” (OED Online). Thus, the providence of the formal is significantly devalued. Formality is, at best, a signifier of empty, superficial protocols and gestures, and thus something to be shunned. For that reason, it is appropriate perhaps to speak of an increasing 'fear of the formal.' 
While the trajectory through which the formal has come to be eclipsed by the informal and spontaneous is particularly noticeable within management and organization studies, the problematization of formal organization is nevertheless tied in with a much larger turn within the social sciences at large. Thus, across a broad range of disciplines, straddling political theory, sociology, and economics, critiques of formal modes of organizing have become ever more prevalent and intense (Stinchcombe, 2001). From Benkler's (2006) embrace of commons-based peer production via Autonomist Marxists' celebration of the multitude (Hardt and Negri, 2004; Lazzarato, 2004), to Hayek’s (1974) praise of spontaneous, self-organizing systems, formal organizations are negatively coded. And while the various ills associated with formal organization include repression of the individual, lack of freedom, inefficient allocation, inflexibility, wastefulness, slowness, and suppressed creativity, the cures to these ills are invariably to be found in spontaneous, bottom-up and informal modes of organizing. From cities (Harvey, 2012) to peer-communities (Bruns, 2009), from societies (Tvede, 2015) to governments (O’Reilly, 2009), businesses (Hamel, 2009), and economies (Arvidsson, 2008, 2009), spontaneous and informal modes of organizing are increasingly positioned as preferable substitutes to formal modes of organization. Although substantial differences exist as to the exact political, cultural and moral goals which are to be accomplished through this shift, the modus operandi of spontaneous and informal organization is cherished by commentators from diverse disciplinary formations and with radically different political beliefs.

In this paper, we explore this 'fear of the formal', outlining key elements of its genealogy and exploring its contemporary manifestation in relation to recent and ongoing reforms of organizational life in a range of contexts, public and private, governmental and commercial. At the same time, we seek to indicate the continuing constitutive significance of formality and formalization for both the securing of organizational purposes and individual freedom. Formality we suggest should not be approached in a morally expressivist manner. We should not confuse 'unjust formality' in terms of the standards set for it by management consultants or social theorists, with formality ineffective for the purposes it holds itself to.

The argument proceeds as follows: First, we provide a short genealogy of how the informal and spontaneous have come to eclipse formality as an organizing principle. In so doing, we are particularly attentive to key moments within the history of Organization Theory and the Sociology of Organization, because 'formal' here has undergone a shift of status from being the distinguishing and defining characteristic with which these fields demarcated their object of study and differentiated themselves 
from the rest of the social sciences, to something that organizing as an activity must dispense with. At the same time, the spontaneous and informal has enjoyed a renewed significance morally and practically, in sharp contrast to its earlier not entirely unproblematic status. Second, having presented this historical account we argue that in spite of all the ills attached to formality within the field of organizational analysis, as elsewhere in the present, there can be no such thing as organization as a distinctive sort of entity without the presence of formality. In making this point, we have recourse to the work of the chief executive, minister of state, and University Pro Chancellor, Wilfred Brown, who rose to prominence in the field of organizational analysis as a result of his involvement in the first major research project undertaken by the Tavistock Institute after the Second World War: the Glacier project. Finally, we conclude by exploring some of the organizational and political effects of the contemporary turn to informality; we suggest that rather than residing with formality, as many critics argue, contemporary organizational pathologies can be traced to the operationalization of the assumption that formality is a fraud that should be dispensed with.

\section{A short genealogy of formal-, informal-, and spontaneous organization}

In the introduction to his book When Formality Works: Authority and Abstraction in Law and Organizations, the organizational sociologist Arthur Stinchcombe (2001, p. 2) observed that whereas formality "used to be a central criterion for the differences between 'formal organizations' and other kinds of social structures”, it has now "become epiphenomenal". As Stinchcombe indicates, several of the early theorists of organization explicitly referred not just to organizations, but to formal organizations, in order to demarcate their specific object of study. Indeed, formal was not merely 'a', but rather the central criterion with which 'organizations' were differentiated from other social phenomena (Barnard, [1938] 1968; Parsons, 1956; March and Simon, 1958; Blau and Scott, 1963; Blau, 1968). Blau and Scott (1963: 5), for instance, made this clear when they stated that in "contrast to social organization that emerges whenever men are living together, there are organizations that have been deliberately established for a certain purpose.” Such organizations, Blau and Scott elaborated, "have not spontaneously emerged in the course of social interaction" (ibid.), but been deliberately constructed with a number of explicit roles, structures and lines of authority in order to achieve specific goals (ibid., see also March and Simon 1958: 14; Barnard 1968: 4; Blau 1968: 297-8). This “formal establishment for an explicit 
purpose", therefore, is "the criterion that distinguishes" Organization Theory "from the study of social organization in general” (Blau and Scott 1963: 5).

While agreement concerning this matter characterized the self-reflective founding of Organization Theory as a distinct "semidiscipline" with a "shared language and a shared set of concerns” (March, 1965: xiv-xv, cf. Lopdrup-Hjorth, 2015), a collection of works emerging from the 1930s, had begun to theorize and inquire into the specific characteristics of, and relationships between, formal organization, on the one hand, and informal- and spontaneous organization, on the other. Notable among these were Chester Barnard's (1968) The Functions of the Executive, Fritz J. Roethlisberger and William J. Dickson's ([1939] 2000) Management and the Worker and Elton Mayo’s ([1949] 1975) The Social Problems of an Industrial Civilization and ([1933] 2003) The Human Problems of an Industrial Civilization. While all of these works contained descriptions of formal-, informal-, and spontaneous organization, they nevertheless at the same time differed somewhat in their assessments of the respective moral and organizational importance attached to these. Whereas Barnard, as we'll see shortly, ascribed a range of positive normative attributes to formal organization, Roethlisberger, Dickson and Mayo tended towards a slightly more critical understanding of formal organization, while simultaneously attaching more weight to informal- and spontaneous organization. After having attended to how the interrelationships between the formal on the one hand, and the informal and spontaneous on the other played out in the works of Barnard, Roethlisberger, Dickson and Mayo, we will move on to show how some of the assessments advanced here gave way to an intensified critique of the formal from around 1960.

Barnard, whose influence on later Organization Theory is probably unrivaled by any other single person (Perrow 1986, p. 63; see also March, 1965, p. xii), wrote his major work at a time when it had not yet become commonplace to refer to Organization Theory as a separate and distinct area of study. For that reason it was necessary not merely to specify why it was important to study organizations, but also to stipulate the defining characteristics of organizations. In so doing, Barnard stated that political theorists and social scientists had not given sufficient attention to what he designated as the "principle structural aspect of society itself”, namely formal organizations (Barnard 1968, p. xxix). This neglect Barnard considered the social theoretical equivalent of "leaving a vital organ out of anatomy" (Barnard 1968, p. 3), because formal organizations were "omnipresent and inescapable” (Barnard 1968, p. 4). Whether they were "governments, government departments, churches, universities, labor units” (p. 4), such organizations performed an abundance of tasks that were central and indispensable to a well-functioning society. Indeed, most of what one 
would find "reliable, foreseeable, and stable" was accomplished by such organizations (p. 4), and if they did not exist, we would, according to Barnard, be in “a state of nearly complete individualism and disorder” (p. 120).

To correct this theoretical neglect, Barnard therefore set out to theorize formal organizations. As a minimal delineation he defined them as systems "of consciously coördinated activities or forces of two or more persons” (Barnard, 1968, p. 73, italics in original). Besides being conscious and deliberate, formal organizations, according to Barnard, were also defined by their purposive nature. Indeed, for an organization to come into being, and to continue its existence, it had to have an overall objective, that is, what Barnard called “the 'purpose' of an organization” (1968, p. 86). This purpose, he stated, was not merely implicit and "axiomatic" in the concept of formal organization (1968, p. 86); a common objective or purpose was also indispensable and of utmost practical importance if an organization was to remain vital. While not necessarily easily formulated in words, the belief in the existence of an overall objective, goal, or purpose, was crucial (Barnard, 1968, pp. 86). ${ }^{1}$

In addition to this representation of formal organizations as an indispensable part of any organizing effort, Barnard, also took 'spontaneous-' and 'informal organization' into consideration. However, the way in which he did so was clearly from the point of view of formal organization. This is evident from the fact that the primary sections of his major work where he attended to these matters (1968, p. 102, 114-123) within Part II of The Functions of the Executive, were titled 'The Theory and Structure of Formal Organizations'. Whereas ‘spontaneous organization' implied a common purpose, and, according to Barnard, for instance took place in putting out a fire, that is, "when two or more persons simultaneously contribute efforts, without the leadership or initiative of any one of them” (p. 102), 'informal organization', conversely, excludes joint purpose by definition, and was therefore considered to be a rather "structureless" and "shapeless mass" that "probably cannot persist or become extensive without the emergence of formal organization” (p. 115, 117). This does not mean that nothing good comes from informal organization. It only meant that one could not know in

\footnotetext{
${ }^{1}$ Barnard, in contrast to later critics, as we will come to see, was careful to distinguish between individual motive and common purpose. Although these could overlap, "under modern conditions it rarely (...) appears to be the case" (Barnard, 1968, p. 89). In keeping with the importance of formality, that is, in emphasizing distinct spheres of competence, lines of responsibility, organization roles, etc., Barnard stressed that "every participant in an organization may be regarded as having a dual personality - an organization personality and an individual personality. Strictly speaking, an organization purpose has directly no meaning for the individual” (Barnard, 1968, p. 88).
} 
advance what the specific outcome of the actions of an informal group, such as, for instance, a mob or a crowd, would be.

Barnard, however, was not alone in taking cognizance of 'spontaneous-' and 'informal organization'. In his discussion of the latter, he referenced, among others, the human relations theorists Elton Mayo, Fritz J. Roethlisberger and William J. Dickson. Like Barnard, these writers were also preoccupied with the relations between formal organization on the one hand, and spontaneous and informal organization on the other. However, in contrast to Barnard, they did not view the interrelationship between these different modes of organization from the point of view of the formal to the same extent. Rather, in the work of Elton Mayo ([1949] 1975, [1933] 2003) and Roethlisberger and Dickson ([1939] 2000) one finds the seeds of critiques of 'formal organization' that would come to be extended and elaborated in later generations of organization scholars, just as one finds an increasing appeal to and of the informal and spontaneous.

One of Roethlisberger and Dickson's major findings was that group behavior among workers resulted in a spontaneously arising order within the workplace that differed markedly from the formal order. In what was to become the key account of the famous Hawthorne Experiments, Management and the Worker, Roethlisberger and Dickson (2000: 524) described how the men at the Hawthorne Plant "had elaborated, spontaneously and quite unconsciously, an intricate social organization around their collective beliefs and sentiments.” This spontaneous social organization showed up as a specific informal organization, which, according to Roethlisberger and Dickson, “exists in every plant” (2000: 559), and without which "formal organizations could not survive for long” (ibid: 562).

The problem pointed to was not merely that organization scholars hitherto had overlooked the importance and necessity of the delicate spontaneity of the informal organization; it was also that this organizational reality either had "no representation in the formal organization at all” or was "inadequately represented” by the formal organization (ibid: 559). As a consequence, schemes, policies, and changes initiated through formal organizational dictates more often than not ended up with consequences that differed markedly from those intended. Whereas Roethlisberger and Dickson's attempt to remedy this problematic consisted in proposing the establishment of a new function of personnel work (2000: 591), Mayo widened the scope of the problem by stating that organizational problems essentially were caught up in a larger metanarrative, where formalization, industrialization and urbanization had created a condition in which the forces through which spontaneous social 
organization could arise had been undermined (Mayo, 1975, 2003). To counter this, Mayo proposed, on the one hand, the establishment of organizations as communities that ideally resembled "pre-industrial societies" where "the spontaneous corporation of skilled groups” prevailed (J.H. Smith 1998: 231), and, on the other hand, he thought that such communities could only "be restored through the creation of administrative elites trained in techniques of social organization and control” (J.H. Smith 1998: 237-238). Hence, in contrast to Roethlisberger and Dickson, who readily identified a spontaneous informal organization arising from workers' individual beliefs, their upbringing, and their general socialization, Mayo thought that the conditions for the flourishing of this spontaneous sociality were significantly hampered, and, therefore, had to be promoted and restored by capable leaders (cf. Lopdrup-Hjorth 2013, p. 268).

With the human relations theorists 'the formal' therefore increasingly began to be associated with various kinds of ills, and yet, the attempt to theorize all that which could not be subsumed under the categories of the formal organization should not merely be seen as an acknowledgement of its “irrepressibility” but also as an attempt to bring the informal organization "into alignment with the formal parts and purposes of the organization” (Grey, 2010, p. 43). The formal and the informal could be in 'disequilibrium' or 'opposition' to each other, which indicated that there was an equilibrium or balance point that - given the right conceptual lenses and interventions - could be attained.

\section{ACCELERATING THE CRITIQUES OF FORMAL ORGANIZAITON}

While Mayo, Roethlisberger and Dickson in this way opened an intellectual horizon within which formal and informal organization could come to stand in tension, or, more fundamentally, opposition, to one another, the unfolding and accentuation of this conflict accelerated from the 1960's, where, according to some theorists, it became increasingly difficult to overcome the ills of the formal. On the one hand this happened with the flourishing of theories that were associated with the second branch of the human relations movement (Perrow, 1986, p. 97); and on the other hand it happened in conjunction with problematizations of the foundations and key concepts that had been central to those who had identified Organization Theory's primary object as formal organization. In combination, these two lines of attack on formal organization merged ethical and political critiques with theoretical and conceptual ones. Formal organization therefore came to be represented not merely as repressive, dangerous, and out of sync with basic human proclivities, but also came to be associated with ill-conceived theoretical justifications that had led the study of 
organizations down a problematic 'managerial' path. We will attend to each of these critiques in turn.

From the 1960s formal organization, with its structures, lines of authority, task specialization, organization charts, clearly demarcated roles, and purposive nature came under repeated attacks from a range of psychologically informed theories of organization. In conjunction with individuals being given "greater freedom and initiative”, "a substantial increase in the educational level of the work force” (Likert, 1961, p. 1-2), experiments with T-Groups, and, not least, a new psychology centered on the notion of 'self-actualization' (Maslow, 1954; Warring, 1991, p. 134-35), the view of organizations, and of those working in organizations, changed significantly. While Mayo, Roethlisberger and Dickson had viewed workers as largely passive, responsive, 'irrational' (Mayo 2003, p. 164-166), and, essentially, objects of manipulation (Perrow, 1986, p. 83), several of those associated with the second wave of human relations, such as, for instance, Rensis Likert, Douglas McGregor, and Chris Argyris, emphasized the inherent creative potential slumbering in workers. Given the right conditions, these theorists reasoned, this creative potential would come to flourish. However, in its way stood all those principles hitherto associated with formal organizations. Whether it was called 'Theory X' (McGregor, [1960] 2006), 'task specialization' or 'chain of command' (Argyris, [1957] 1970, p. 60-61), 'exploitative authoritative’ organization (Likert, 1961; Perrow, 1986, p. 100), or something different, the "authoritarianism" of "formal power" was seen as leading "to mistrust, conformity, inflexibility, apathy, and a general withdrawal of efficiency" (Warring, 1991, p. 118).

One of the clearest and earliest expressions of this accelerating critique of formal organization was Chris Argyris’s ([1957] 1970) Personality and Organization. Rather than pointing to how the formal and informal could be in disequilibrium, or at odds with one another, as Mayo, Roethlisberger and Dickson had done, Argyris stated that there was a more important conflict at stake which consisted in a fundamental "lack of congruency between the needs of healthy individuals and the demands of the formal organization" (Argyris 1970, p. 233). On the one hand stood the individual with his or her culturally and historically shaped needs for self-actualization, and on the other stood the formal organization, which, given its inherent dysfunctions, suited "immature and even mentally retarded individuals" rather than sane people (Argyris, 1970, p. 67). Thus, the problem was not bad and ill-conceived formal organization, that is, something which could be corrected. Rather, it was formal organization and its principles per se that was to be blamed for all the ills haunting organizational life. Whether it was task specialization, managerial coordination, authority, or the chain of 
command, Argyris saw all of these as inherently at odds with the development of healthy and mature individuals, and, therefore, as outdated and harmful organizational principles that ought to be dispensed with.

Given this basic incompatibility between the dictates of the formal organization and the needs of healthy individuals, those inhabiting formal organizations inevitably found themselves "full of pent-up" tensions (Argyris, 1970, p. 230). To alleviate this, that is, in Argyris's words, "to maintain a minimum level of health" and to rid themselves of the tensions produced by the formal organization, individuals by necessity had to resort to their own 'informal plays' (Argyris, 1970, p. 229). And the only way they could do this was through informal organization. The informal organization therefore came to be considered as the sane individuals' mode of processing and coping with all the ills generated by formal organization. Most managers, however, were unable to see this causation, and consequently diagnosed 'the informal behavior as 'bad.' Basing their action on the logic of formal organization, they try to neutralize or do away with the informal behavior through directive leadership, management controls, and pseudo human relations programs” (Argyris, 1970, p. 231). In so doing, Argyris continues, "they only tend to 'compound the felony' that the formal organization is committing every minute, every hour of the day, because they tend to increase the employees' feelings of dependence, submissiveness, and subordination” (ibid.).

In conjunction with discrediting and even 'criminalizing' formal organization, Argyris attached normative weight to a range of characteristics associated with informal organization. For instance, in conjunction with reviewing various literatures on organization and management, he contrasted informal, spontaneous, and emergent leadership with formal authority, also referred to as 'headship' and 'domination.' Quoting extensively from Cecil A. Gibb’s (1954) article "Leadership” from the Handbook of Social Psychology, it became apparent that Argyris thought it was important that informal "leadership" should "be distinguished, by definition, from domination or headship.” Whereas formal authority "is maintained through” a "dominance relation", the emergent or informal "leader's authority is spontaneously accorded him by his fellow group members” (Gibb quoted in Argyris, 1970, p. 7071). And whereas the former was entirely dependent upon a role and a position artificially created in conjunction with the dictates of the formal organization, the latter's position, on the contrary, arose as recognition of the leader's ability to contribute "to group goals" (ibid.). The spontaneous, emergent and informal leader's position therefore was viewed as more fair and benign, than the autocratic headship and domination associated with formal organization. 
While Argyris's critique of formal organization was perhaps the clearest and most pointed, it was, as already mentioned, merely one example among a range of likeminded critiques that emerged in the 1960's to problematize formal organization, and, in particular, to show how such organization crushed the preconditions for selfactualization and individual initiative (e.g. McGregor, [1960] 2006; Whyte, [1956] 2002). In conjunction with these practical, ethical and political critiques, however, another complementary stream of critique of formal organization was also beginning to be set in motion. Yet instead of starting from the premise of self-actualization, this critique targeted the very theoretical and conceptual foundations of Organization Theory, as it had developed throughout the preceding decades. Of significance here was a questioning and skepticism directed towards 'formal organizations' as the proper key object of Organization Theory and the Sociology of Organization. In a pioneering article from 1968, which was followed by the book The Theory of Organizations in 1970, the organizational sociologist David Silverman stated that the study of organizations had been led down a slippery and unsustainable path by narrowing and restricting its focus to formal organization. In essence, Silverman argued, organization scholars had become caught in a 'systems orthodoxy' when they ought rather to establish "empirically the conceptions of ends and needs held by" organization members (Silverman, 1968, p. 223). By utilizing notions such as organizations' 'purposes,' 'goals' and 'needs', organization scholars, according to Silverman, reified organizations, that is, attributed "apparently human motivations to inanimate objects” (Silverman, 1968, p. 223, see also Silverman, [1970] 1987, p. 3); in so doing, they effectively conceived of organizations and their 'goals' and 'needs' "as things which are separate from the definitions and purposes of their members" (Silverman, 1987, p. 219).

According to Silverman (1968, p. 234), this “metaphysical functionalist” approach to organizations was fundamentally misguided. By taking formal organizations, and their goals and needs, as key objects and conceptual points of departure, Barnard, Blau and Scott, and all the rest of those theorists that had privileged the study of formal organizations, had, allegedly, become blind not merely to the minute, empirically observable details and conflicts traversing organizations, but also demarcated their object of study too sharply from sociology, thereby "excluding or, at best, de-emphasizing the type of problem which arises within the structure of the society rather than within the organization” (Silverman, 1968, p. 235). Furthermore, in stressing 'formality', 'organizational goals' and 'organizational needs,' the 'systems orthodoxy' approach, according to Silverman, implicated and favored a management perspective on organizational problems. Thus, rather than presenting a 
neutral perspective on organizational matters, 'systems orthodoxy' was criticized for privileging and legitimizing the viewpoint of management at the expense of other organizational members. By favoring formal organizations, and their 'goals' and 'needs', those studying organizations were therefore led to accept management problems and agendas as their own (Silverman, 1968, p. 229) instead of attending to the conflicts and power plays through which certain actors and groups within organizations were capable of setting the agenda at the expense of less powerful actors and groups. In this sense Silverman's theoretical critique of formal organizations resonated with Argyris's critique in that it also emphasized an intimate connection between formal organization and managerial abuse of power on the one hand, and an individualistic, if not self-actualizing, point of departure at the expense of an organizational point of view on the other. ${ }^{2}$

\section{ANTI-FORMALITY AS A WIDELY DIFFUSED STANCE}

In the slipstream of these critiques, formal organizations, and the kinds of study privileging formal organizations, were challenged in a hitherto unprecedented way. Not only were formal organizations beginning to be viewed with suspicion, but the discipline previously devoted to the study of such organizations, that is, Organization Theory, was also beginning to be subject to internal critiques for privileging formal organizations as its primary object. We will end this short genealogy by indicating how in the final decades of the twentieth century, and the first decade of the twentyfirst, an intensification of problematizations of the formal occurred that, in various ways, carried the critiques and contestations of formality forward and transformed it from a marginal and oppositional position into a common and widely diffused standpoint shared among a varied group of exponents. However, since we cannot do justice to the manifold ways in which formal organization - directly as well as indirectly - has been criticized from the 1970s onwards, we'll here restrict ourselves to highlighting two important trajectories: On the one hand, we'll indicate how economic and popular managerial variants of organizational analysis further undermined the theoretical and practical foundations of formal organizations while simultaneously finding cures to these in spontaneous and/or informal modes of organizing; on the other, we'll point to the way in which exponents within organizational sociology and related critical lines of thought, from a different angle of attack, developed complementary lines of critique. In so doing, we'll stress how the

\footnotetext{
${ }^{2}$ Due to these commonalities, Perrow's remarks targeted at Argyris and other exponents of the second wave of human relations theory could also be directed towards Silverman: "One cannot explain organizations by explaining the attitudes and behavior of individuals or even small groups within them. We learn a great deal about psychology and social psychology but little about organizations per se in this fashion” (Perrow, 1986, p. 114; see also Strauss, 1969, p. 267).
} 
mutual suspicion and critique of formal organizations voiced within these otherwise different theoretical traditions converged in what we have termed a 'fear of the formal'.

From the 1970s and onwards, several of the critiques of formal organizations voiced by organization theorists throughout the 1960s were extended by a range of economic theories of organization broadly referred to as organizational economics (Barney and Ouchi, 1986). While not dismissive of authority and control as such, organizational economists nevertheless erased the frame of reference through which formal organization had initially been conceived, and in its place put a reductive image of self-interested actors that, whether in or out of organizations, acted in accordance with narrow economic imperatives. Of particular importance in this regard was agency theory, pioneered by a group of economists at Chicago University (notably Eugene Fama, Michael Jensen, and William Meckling). Agency theory brought a whole new conceptual package to organization theory and, in so doing, replaced previously dominant tropes and notions with a vocabulary based on economic reasoning (Jensen and Meckling, 1976; Jensen, 1983; Perrow, 1986: 224-236; Khurana, 2010: 313-326). Arguing that organization theory was "still in its infancy", Jensen (1983, p. 324) proclaimed a "revolution in the science of organizations". Rather than starting from the premise that organizations were distinct entities, where different organizational personas worked together to pursue (one or several) organizational goals, agency theory instead postulated that organizations, in essence, behaved like markets where rational individuals, as in all other walks of life, pursued their self-interests. All organizations, whether public or private, were essentially reducible to "legal fictions which serve as a nexus for a set of contracting relationships among individuals" (Jensen and Meckling, 1976, p. 310). Substantiating this claim, Jensen and Meckling (ibid.) explained that there
is in a very real sense only a multitude of complex relationships (i.e., contracts) between the legal fiction (the firm) and the owners of labor, material and capital inputs and the consumers of output. (...) The firm is (...) a legal fiction which serves as a focus for a complex process in which the conflicting objectives of individuals (...) are brought into equilibrium within a framework of contractual relations. In this sense the "behavior" of the firm is like the behavior of a market, that is, the outcome of a complex equilibrium process.

In setting forth these propositions, Jensen and Meckling casually erased several decades of organizational theorizing, and, in the process, furthermore hopelessly confused such central notions as 'firms' and 'corporations', thereby completely 
misrepresenting the language and categories of corporate law (Robé, 2011). Although considering control essential for obtaining viable principal-agent relations, agency theorists erased the whole frame of reference through which earlier organization theory had viewed formal organization. This was not least due to the fact that the theory on the one hand excluded the possibility of an overall organizational purpose, and on the other hand excluded the reasonability of the assumption that managers, or any other organizational 'agent', acted in the service of the organization, rather than solely with an eye to maximizing their own economic returns.

If Silverman had conceived of formal organizations, and in particular of such organizations' needs and goals, as metaphysical reifications that glossed over the real, concrete and contradictory needs and aspirations of different organizational members, agency theorists, from an economic point of view, seemed to make a somewhat complementary point. They also considered formal organizations as 'fictions', just as they discarded any overall, substantive organizational purpose (besides maximizing shareholder value). Instead, agency theorist started from the proposition that what counted was the self-interest of individuals and the fact that people behave opportunistically.

Whereas it fell outside the scope of Silverman's account to solve the problems of organizational life, agency theorists could point to the way in which their 'fictitious contractual entities' could solve all conflict. By aligning the interests of the agent with the principal, everybody could pursue their own interest in a mutually beneficial manner without subscribing to an overall organizational goal. Thus, through a web of contractual relations, the 'behavior' of the organization could simply be depicted as similar to the behavior of the market, that is, a spontaneous process through which conflicting individual interests could be brought into equilibrium. For that reason, it therefore also made no sense to distinguish between organizational identities and individual identities (as Barnard had done in setting forth his theory of formal organization), because there was no reason to presume anything but opportunistic behavior. In essence, there were only self-interested individuals pursuing their goals either in markets or in organizations that ought to resemble markets. In the words of the organizational economist Oliver Williamson, organizations could therefore simply be considered as "a continuation of market relations, by other means" (1991, p. 162, emphasis in original).

While agency theory has been one of the most pervasive (and dangerous) theoretical currents in recent decades (Perrow, 1986; Ghoshal, 2005; Dobin and Jung, 2010; Styhre, 2015), the market, as well as related modes of spontaneous organization, has 
also seeped into other theoretical accounts as a superior and preferable alternative to formal organization. In particular, from the 1980s onwards a significant number of highly influential, populist management tomes were quick to pick up on the ways in which organizations ought to be reconceived in much more plastic, spontaneous and ephemeral terms than those characterizing formal organization. Management theorists here discovered and revitalized elements of the vocabulary previously associated with 'informal organizations', and articulated several of the key components of this notion within new concepts such as 'culture', 'self-organization', 'internal markets', 'ecosystems', and so forth. (e.g. Peters and Waterman, 1982; Peters, 1992, 1996; Schein, 1992; Wheatley and Kellner-Rogers, 1996; Ramaswamy and Gouillart, 2010). As a complement to the cool, scientistic vocabulary of agency theorist, management thinkers, in a more seductive and passionate prose, urged practicing executives to disregard and overturn formality as an organizational ideal.

Tom Peters, for instance, has argued that it was necessary to "get rid of the entire formal organization” (Peters, 1994: 29-30), to “destroy the hierarchy” (Peters, 1992: 131), and to give the market "free rein, inside and outside the firm" (Peters, 1992: 480). In Peters' ideal, spontaneous, market-like, anti-formal organization “constant informal chatter goes on” (Peters, 1994, p. 179), all organization members are given "latitude to perform spontaneous acts" (Peters, 1994, p. 266), and to assume they have "absolute authority until somebody tells" them otherwise (Perle, quoted in Peters, 1994, p. 110). Instead of being 'boxed in', managers across public and private organizations were called upon to become revolutionary renegades that tore down hierarchies and overturned established lines of coordination, authority, and control. Thus, the prevailing credo seemed to be: “we don’t care about formalities” (Kolind, quoted in Peters, 1994, p. 29-30).

This anti-formal vocabulary has since then become a common ingredient in the contemporary prevailing management idiom (Boltanski and Chiapello, 2005). It is therefore unsurprising that Gary Hamel, another of the world's most influential business thinkers (Kneale, 2009), concurs with Peters when he states that the "formal hierarchy overweights experience”, "misallocates power” and "breeds sycophants" (Hamel, 2014). In Hamel's anti-formal prose, tellingly presented in an article called "Bureaucracy must die", it is stated that if "an organization is going to outrun the future, individuals need the freedom to bend the rules, take risks, go around channels (...) and pursue their passions” (ibid.). However, rather than stressing 'the market' as the 'model coordination device' through which this is to be achieved, Hamel, in a cluster of books and articles on 'management innovation' (see e.g. Hamel, 2006, 2009; Hamel and Breen, 2007), argues for the radical potential to be gained from 
harnessing the spontaneous modes of organizing found in open source communities. In contrast to dysfunctional formal organizations, Hamel envisions that the adoption of the "evolving creative anarchy" characterizing open source communities will allow organizations to become "fit for the future" (Hamel, 2009, p. 5).

In setting forth such propositions, Hamel is in agreement with a huge portion of the business literature that has recently discovered how businesses can gain access to hitherto unimaginable sources of creativity and innovation by utilizing informal and spontaneous modes of organizing. The prevailing wisdom on this matter seems to be that businesses at the very least need to establish relations with users, usercommunities, social movements, and other extra-organizational capacities, and, more often than not, also emulate their informal, spontaneous modes of organizing in an attempt to become creative and innovative (e.g. von Hippel, 1986, 2006; Normann and Ramírez, 1993; Prahalad and Ramaswamy, 2000, 2003, 2004a, 2004b, 2004c; Vargo and Lusch, 2004, 2010; Helm and Jones, 2010; see also Lopdrup-Hjorth, 2013).

Thus, in key texts within the pro-business literature we see a strong anti-formal stance being promoted in conjunction with a conceptual celebration of various informal and spontaneous modes of organizing. Whether this agenda is pursued through attempts at depicting organizations in the image of market-like relations (e.g. Jensen and Meckling, 1976; Peters, 1992, 1994), open source communities (e.g. Hamel, 2009; Hamel and Breen, 2007), ‘ecosystems’ (e.g. Ramaswamy and Gouillart, 2010), or something similar, the providence of the formal is significantly devalued.

As already indicated, however, this 'fear of the formal' has also made its presence felt within organizational sociology, and related critical lines of thought, that traditionally have been less concerned with - if not directly opposed to - the tightknit connections between markets and contemporary management thought. Some of the roots of this critique go back to the wave of perspectives that began to proliferate within Organizational Sociology from the 1970s. Those approaches, including, not least, resource dependence theory and institutional theory, had clear affinities with a "view of organizations as (...) serving the interests of some people more than other (...), and as being built upon and sustaining power relations" (Donaldson, 1995, p. 15). Rather than being preoccupied with how to develop and sustain appropriate formal organization, resource dependence theory and institutional theory instead shifted their respective concerns towards "attention and information manipulation" on the one hand, and "the demands and expectations of the wider institutional environment" on the other (Donaldson, 1995, p. 16). Due to this, institutional theory, for instance, 
could depict formal organization as a 'rational myth' that merely served as a tool to gain legitimacy, rather than supporting the coordination of the actual work performed by the organizations' members (Meyer and Rowan, 1977). This 'decoupling', as institutional theorists called it (ibid.), were part and parcel of a more profound theoretical reworking and problematization of formal organization. Thus, in addition to resource based theory and institutional theory, a range of anti-formal theoretical currents began to proliferate. From critiques that revolved around 'the ideology of form' and linked Organization Theory to "a tyranny without a tyrant” (Schuman, 1978, p. 69), to critiques that problematized 'the ethic of organization' for its incapacity to integrate the whole individual (Denhardt, 1981).

\section{Of particular importance, however, were Burrell and Morgan’s Sociological} Paradigms and Organizational Analysis. It not merely picked up on Silverman's critique of the 'metaphysical functionalism' associated with the study of formal organization, but also provided new philosophical and social scientific points of departure for those critical of the primacy hitherto attached to formal organization as the principle concept and object of organization theory. Building on Kuhn's (1970) notion of paradigms, Burrell and Morgan stated that all organizational theories explicitly or, more often than not, implicitly carried with them ontological and epistemological assumptions that, when disclosed, could be used to classify these theories in accordance with incommensurable traditions of thought. Rather than understanding distinct organizational theories in close association with practical problems, or with what has later come to be designated as a 'practical stance' (du Gay and Vikkelsø, 2014: 737-38), Burrell and Morgan emphasized that "all theories of organisation are founded upon a philosophy of science and a theory of society" (Burrell and Morgan, [1979] 2014, p. 119). On this premise it then became possible to abstract from the concerns of specific theories, and to outline four overall sociological paradigms to which four distinct modes of organizational theorizing could be linked. ${ }^{3}$ In accordance with their Kuhnian inspiration, Burrell and Morgan stated that they did not "attempt to criticise and evaluate" any of the paradigms from an outside perspective (ibid., p. xii). Nevertheless, 'functionalist organization theory', that is, the majority of the established tradition of organizational theorizing, was portrayed as 'ideological' and 'conservative', as well as having a "managerial bias" "built into" its "model" (p. 220). As such, it was also presented as a hindrance to the flourishing of alternative modes of organizational theorizing that, though less developed, were just

\footnotetext{
${ }^{3}$ Burrell and Morgan's sociological paradigms were respectively called (I) functionalist sociology, (II) interpretative sociology, (III) radical humanism, and (IV) radical structuralism. The modes of organizational theorizing attached to these were (i) functionalist organization theory, (ii) the interpretative paradigm and the study of organizations, (iii) anti-organization theory, and (iv) radical organization theory.
} 
as legitimate as the functionalist approach. In this sense, the book offered itself as laying the groundwork, as brushing away all contingent matters, and digging down to what was considered of overall importance, that is, to "the first principles" and "the philosophical traditions" from which the respective organizational theories derived (p. 397). And rather than seeking integration, synthesis, and mediation, the fear of having the respective alternative paradigms subsumed under the functionalist orthodoxy led Burrell and Morgan to advocate ‘paradigm isolationism' (ibid.).

Interestingly, however, none of the three alternative 'non-functionalist' modes of organizational theorizing gave much weight to organizations in their own right, and even less to formal organization. This was due to the fact that organizations either were considered to have a weak ontological status, and/or were depicted as derivatives or epiphenomena of more foundational and encompassing societal structures and totalities. As Burrell and Morgan argue, from "the standpoint of the interpretative paradigm, organizations simply do not exist” (p. 260), while they from the standpoint of 'anti-organization theory' is viewed as "reified social constructs" and "alienating 'intermediaries' which serve to mystify human beings in their attempt to comprehend and appreciate the nature of the totality in which they live.” (p. 311). Finally, from the perspective of 'radical organization theory,' organizations "can only be understood in terms (...) of the wider social formation within which they exist and which they reflect” (ibid., p. 368). For that reason, Burrell and Morgan argue, a "theory of organisations consonant with radical structuralism would involve not so much the development of a radical theory of organisations as such, as a radical theory of society in which organisations are accorded a central role” (p. 390).

Due to this, the central status previously accorded to formal organizations could not, and should not, be carried over into any of the three alternative perspectives. If anything, the task for proponents of 'radical separatism', as Burrell and Morgan's approached was dubbed, was to break out of the 'psychic prison' (Morgan, 1986) of formal organizations, because, as "the prison metaphor suggests", the "'formal' organization is a disciplined space, with the term 'formal' being an imperative that privileges order" (Hassard et al., 2008, p. 31-32). A sustained impulse in alternative and critical accounts of organizational theorizing has since Burrell and Morgan's book consisted in highly sophisticated theoretical attempts at moving beyond the confines of 'the prison' of 'the formal'. And while the specific attempts at this have been assembled under various normative ideals, several of the experiments have been conducted in the name of giving voice to 'otherness', 'resistance', the 'irreducible excess' of organizational life, 'processes', 'disorganization', and all the rest of that which allegedly is repressed by the categories associated with the formal. Although 
having been a huge theoretical success, measured by number of conferences organized, journals established, and published articles, scholars implicated in the critical enterprise have begun questioning whether the acrobatic epistemological and ontological maneuvers have had the benign effects initially hoped for (e.g. Jackson and Carter, 2009; Alvesson, 2013).

Our contention here would be that much of organizational sociology and critical organizational theorizing have been no less implicated in undermining formal organization than has organizational economics and popular management theorists. Both have - in their respective ways - attempted to overturn the principles and categories associated with formal organization, and in their place, often with reference to ideals of freedom, liberation and resistance, promoted notions that rhymes with 'spontaneity’, 'disorganization', 'informality', 'excess', 'fluidity', etc. If there is a difference, it is perhaps less in the respective concepts and philosophical underpinnings supporting these respective gestures, but rather that whereas the critical organization scholars to a significant extent have failed in their good-hearted attempts (Jackson and Carter, 2009), agency theorists and popular management scholars have, unfortunately, been more successful in shaping organizations in their image (Ghoshal, 2005; Dobin and Jung, 2010; Khurana, 2010). However, 'the fear of the formal' uniting both of these camps represents a major challenge that has to be overcome. In the final part of the paper, we will take a few steps in this direction. First, we will argue that in spite of all the ills attached to formality within the field of organizational analysis, as elsewhere in the present, there can be no such thing as organization as a distinctive sort of entity without the presence of formality. In making this point, we have recourse to the work of the chief executive, minister of state, and University Pro Chancellor, Wilfred Brown. After having presented this, we conclude by exploring some of the organizational and political effects of the contemporary turn to informality, 'excess', 'spontaneity', etc.; we suggest that rather than residing with formality, as many critics argue, contemporary organizational pathologies can be traced to the operationalization of the assumption that formality is a fraud that should be dispensed with.

\section{Formality as a cornerstone of Organization as a category}

'Making decisions is always difficult because there is always a lapse of time before we know whether we acted wisely. But if we are to be judged on every occasion not only on the wisdom of our decisions themselves, but also on whether we were correct in assuming that the responsibility was or was not within our authority, then 
our work lives will be intolerable...Thus, there is a minimal degree of formalization which must exist if we are individually to possess explicit knowledge of the discretion which we are authorized to use, and will be held responsible for using. Formalization of organization delineates roles and role relationships; formalization of policies makes clear to people the area in which they have freedom to act. Without a clearly defined area of freedom there is no freedom. This, in fact, is a very old story...there is no real freedom without law.' (Wilfred Brown, 1965a: 69-70)

The first major research project undertaken by the Tavistock Institute of Human Relations was an investigation into joint consultation in industry in the UK. It involved work in one enterprise, the Glacier Metal Company, for two and half years between 1948 and 1950, and deliberately ranged more widely than reference to 'joint consultation' might suggest. Indeed, over three decades from the beginning of the study its director, Elliott Jaques, and the Managing Director of the company, Wilfred Brown, both individually and collectively, developed a programme that became recognized in its time as having as significant an impact on organizational and management thinking as the Hawthorne experiments, but which is now largely relegated to a footnote in the history of organization theory. Of the two, it was Wilfred Brown, who elaborated a distinctive approach to Organization Theory as a 'practical science' (du Gay, 2015; du Gay \& Vikkelsø, 2014), one that still possesses considerable significance today, or so we shall argue. As Alistair Mant (2007) has put it, 'Brown was in the great tradition of pioneers of industrial practice, in staying with the problems, devising empirical solutions, and developing theory the while'. He continues, 'Brown was about clarity, precision of concept, formality, and the centrality of authority as liberating factors'. For many contemporary organizational analysts, as we have indicated, formality and authority are the antithesis of flexibility and liberty, not their concomitants. It is unsurprising, then, that Brown is no longer a household name in the field of Organization Theory. That does not mean, though, that his formulations possess no traction, for as Weber had it 'not liking is hardly refuting' (quoted in du Gay, 2013: ) As Brown indicated with characteristic frankness in The Glacier Project Papers, 'some of the current theories about organization... seek to explain the impact of people on the policies which govern the operation of the company in terms of theories about the psychological interaction of groups and of the degree of identification of the individual with the company. Formal organization is thus seen as something that may disrupt these informal mechanisms of association' (Brown, 1965b: 158. Emphasis added). For Brown, such suspicion or overt denigration of formality and formalization 'distorts the whole frame of reference within which organization as a subject is considered' (ibid). Between 1939 and 1947, as Chief Executive at Glacier, Brown admitted he followed both human relations and 
group relations orthodoxies which were less than favourably inclined to 'formality', equating them with instrumentalism, rationalism and technicism, with the effect that the structure of roles and their relation one to another within the Glacier organization became 'hopelessly confused. The result was a dangerous weakening of the authority of managers and no consequential feelings of freedom or satisfaction on the part of the members of the company' (ibid). This confusion and the consequent negative impact upon organization, he indicated, was in no small part due to the unorganizational nature of much human relations and group relations thinking. For Brown, the latter schools often assumed that the actual job, its technology and its mental and physical requirements were relatively unimportant compared to the social and psychological situation of people at work: 'Organizations exist to co-ordinate the...work of...people towards a common series of tasks. If we are to establish sound, viable organization, then we must understand the nature of work. We must be able to talk about its content in explicit terms' (Brown, 1965a: 72-73) - i.e. formally. In Exploration In Management, he succinctly sets out this credo

Effective organization is a function of the work to be done and the resources and techniques available to do it. Thus changes in methods of production bring about changes in the number of work roles, in the distribution of work between roles and in their relationship to one another. Failure to make explicit acknowledgement of this relationship between work and organization gives rise to non-valid assumptions, e.g. that optimum organization is a function of the personalities involved, that it is a matter connected to personal style and arbitrary decision of the chief executive, that there are choices between centralised and types of de-centralised organization etc. Our observations lead us to accept that...organization must be derived from an analysis of the work to be done and the techniques and resources available (Brown, 1965b: 42, Italics in original)

For Brown (1965a: 64-65), it was clear that unless prescribed boundaries were set on the decision making work that employees undertook within an organization, it would be impossible to co-ordinate their work 'towards a common end'. If top management did not set co-ordinating policies which prescribed the discretion of managers throughout the organization, individual managers would be 'entitled to make decisions that could create chaos'. This is because without prescribed boundaries to their discretion, managers would not know where their 'authority and responsibility to make decisions starts or finishes'. They could not then be held accountable 'either for failure to make necessary decisions or for making decisions which, in fact, usurp the authority' of their own managers. As a result, work and thus 'organizing' would be conducted in 'a twilight of continuous uncertainty' (Brown, 1965a: 63). 
If the need for formal organization is denied and as a result there are no written or explicitly recognised prescribed bounds to the work roles, then, clearly, no one really knows what decisions he or anybody else is authorised to make. Every time an individual in the company faces a problem, his first thought would have to be: 'Is it my responsibility to deal with this or not?' In the absence of prescribed bounds he does not and cannot know. Therefore he will have to decide first whether or not to act. Then, if he decides to do so, he will have to make decisions on what action to take. But, once he has made his decision, others may question his right to do so. His manager may 'bawl him out' or may praise him for 'showing initiative'; the individual does not know in advance which response he will get... Neither criticism can be valid unless the discretion in the role has been made explicit. There is need to avoid situations in which the use of personal networks, manipulation of other people, lobbying of support etc, is required by the individual to discharge the work of his role. The absence of clear-cut statements about authority, responsibility and task, create such situations...The degree of formal organization required is that which will ensure that all necessary decisions are made which will keep at a low level interpersonal jealousy and confusions about authority; which will avoid leaving people in a continual state of uncertainty as to how far they can go in making decisions, and which will prevent individuals assuming personal positions of power and influence which leave no connection with the degree of authority required by them to perform the tasks allotted to them' (Brown, 1965a: 69 and 1965b: 154-55).

For Brown (1965b: 153), morally expressivist appeals to 'informality’ as the bedrock of organizational creativity, innovation, freedom and flexibility were 'the converse of my business experience'. They were, rather, appeals to dis-organize; to return to 'a natural condition' in the Hobbesian sense. As Brown (1965b: 153-54) put it, ‘a deliberate policy of leaving organization unformulated is tantamount to the deliberate setting up of a situation of anarchy. I use the word 'anarchy' in its original sense, i.e. 'the want of government in a state’'. Echoing Hobbes’s (1991) (in)famous statement, 'where no Law, no Injustice', Brown argues

It is not absence of law, which allows creative use of discretion, but an explicit area of freedom bounded by the law which reduces anarchy and allows the individual to make his (sic) contribution...A little reflection will surely enable each of us to see that we want a system of law, despite the fact that at times we find it irksome, first, because we desire to be protected from the effect of the unlimited decisions of our fellows and, secondly, because without limitations on our freedom of decision, we must carry unlimited responsibility'. 
Brown (1976: 289) stressed the need for an explicit acknowledgment that what he called the 'executive system ${ }^{4}$ ' was 'brought into being to perform the work of the company, that its structure must be a function of such work, that it must be capable of constant adaptation to match the changes in the work, and that the total work must be divided between all the roles in the Executive System'. He then posed the rhetorical question: To 'what extent is this to be done with deliberation and in a statable manner', in other words, 'formally', and, to what extent is it 'to be left to be decided by the pressure generated by group and individual interaction', in other words, informally? (Brown, 1976: 289). His answer is clear and precise: 'the salient result of the latter process is that the people involved in the situation lack full and consistent knowledge of who does what. The assumption made by some is that this is a situation of liberty for the individual, but is it not more accurate to say that such a situation is one where the right to do certain types of work is decided by the competitive ambitions and power positions of the individual concerned? Jones may well feel a need to carry a certain area of responsibility but, supposing that Smith equally feels that his needs can be met only by carrying that same responsibility, what then? If they are left to fight it out, that can scarcely be called a situation of freedom for either of them' (Brown, 1976: 289). Nor would it be a situation in which the efficiency of, or indeed prospects of survival for, the enterprise (and thus the securing of the purposes for which it was instantiated) was enhanced. No doubt informal groups are capable of improvising a kind of order, but what the latter is and how it contributes to the securing of an overall organizational purpose can only be known after the event, as a historical fact; there will be no prior, logistical guarantees. The latter, after all, is the provenance of ‘formality’ (Stinchcombe, 2001).

Even at the time of its development much of what Brown articulated about the relationship between authority, formality and organization appeared counter-intuitive, and, as a result, out of step with contemporary organizational opinion (Gray, 1976; Mant, 2007). This is even more so nowadays, when, as we have noted so much work in organization theory has adopted a metaphysical stance towards its core object, with the result that once key concepts in the field, including 'authority', 'formality' and even 'organization' are deemed anachronistic and largely irrelevant to contemporary concerns. This fear of the formal, however, is far from salutary. In our discussion and concluding comments we will first indicate some of its practical effects, and after this address some of its theoretical implications.

\footnotetext{
${ }^{4}$ Brown(1965c: 307) defined an 'Executive System' as comprising 'the network of positions to which the company's work is assigned. It is made up of positions which shall be called 'Executive Roles'. The executive system includes all members of the operating organizations, a member being in his (sic) role while he is carrying out his job responsibility.'
} 


\section{Formality as a civilizing instrument: discussion and concluding comments}

In his prize-winning trilogy charting the career of an Australian woman employed in the League of Nations in Geneva during the inter-war years, Frank Moorhouse has some interesting things to say about the various different ways one might come at the relation between formality and informality in organization.

The story of Edith Campbell-Barry, a would be-ideal typical bureaucrat, is told against the rise and fall of the fortunes of the League, which is, itself, for Moorhouse it seems, a model of the ideal-typical public organization. At an early point in Grand Days, the first book in the series, soon after her arrival in Geneva, we find Edith stealing in and out of the office of the Secretary General of the League. Edith is not an official leader of the institution. Rather, she is a recent and rather junior recruit. However, she is a very principled new recruit and is keen, impatient, even, for the League to live up to what she considers to be it's better nature.

Edith is, in fact, impersonating the real Secretary General, Sir Eric Drummond, by using his office, his official stationary, and his forged signature to send our letters to groups around the world that Edith thinks deserve the official support of the League. She is convinced that what she is doing, whilst informal, spontaneous, covert and unofficial, is in fact ethical because it is in the cause of true principle, as she sees it. She literally cannot bear the thought that those in need of support are failing to receive it because of the highly bureaucratic way in which the League's operations are conducted. The organization's cumbersome, formal rules and due process obligations undermine its capacity to live up to its pressing moral obligations, as she sees it. She wants to bypass all this red tape and get things done ASAP.

At a crucial juncture, however, one of Edith's colleagues, Florence, who has become aware of what Edith is up to, asks her to use her access to the Secretary General's office to send a memo out internally to some of their colleagues. Florence has none of Edith's high-minded zeal, she just wants them to concoct a humorous message under the auspices of the Secretary General's office so that their colleagues will be impressed by their wily skills. 
At this point, Edith begins to have doubts. She wonders what would happen if everyone took it upon themselves to act as she had, and, in effect, to 'pursue private policies by stealth'? How dysfunctional and potentially catastrophic for the fulfillment of the League's 'core task' or purpose this could be. Edith suddenly sees the episode from the Secretary General's point of view. And from this perspective she gets a sense of how important it is for employees to act within the confines of their respective offices, and to be on guard against the temptations of informality, impatience, impetuosity, and heart-led enthusiasms. She begins, indeed, to see the significance of 'formal organization' and what Weber termed 'the ethos of bureaucratic office-holding'

'Formalities and procedures were the wisdom of human organization and were in themselves civilizing instruments. She knew that now. When she was younger she'd opposed all red tape. Not any more. Red tape was often just a way of causing a pause in the impatience of things so that everything could be properly checked and considered.' (Moorhouse, 1993: 178)

There is a particular lesson about seeing formality as a fraud to be drawn from this tale, and about the problems that attend the institutionalization of a disposition of 'restless eagerness', or 'enthusiasm', and it is one which has been learned, often at some cost, time and again in any number of organizational settings. It is one that Weber articulated in his political writings, and one with which Franz Kafka (2015; du Gay, 2008), perhaps surprisingly to some, concurred. We find it articulated in recent times, for instance, in official investigations into events surrounding the decision to go to war in Iraq conducted on both sides of the Atlantic (in the UK, The Hutton and Butler Inquiries, for instance), and in official investigations into various corporate collapses in the wake of the financial crisis (the Valukas report into Lehmans, the UK Parliamentary Committee on Banking Standards report into HBOS, for example).

When one dispenses with formality and in its place puts 'informality', 'spontaneity', and 'improvisation' as signposts for practical organization, it is only a matter of time before organizations start to disintegrate, responsibilities become hopelessly confused, and organizational members are invited to pursue private priorities at the expense of organizational goals. Whether in the public or private sector, the necessity of having guidelines for conduct, and clearly demarcated roles, is of paramount importance.

In the public sector, as the story about Edith at The League of Nations illustrates, the antipathy towards restless eagerness, enthusiasm, or impatience inherent in 'a 
bureaucratic ethos' has its own raison d'être. While it is easy to see how such an ethos can be viewed by politicians, disruptive innovators and others as a license to obstruct, it was, until comparatively recently, generally considered indispensable to the achievement of responsible (as opposed to merely 'responsive') government, because it was seen to balance and even complement political will, making governance more effective in the long run. As the American scholar John Rohr (1998) suggested, the bureaucratic ethos is in important respects necessarily unresponsive. The role accorded to governmental bureaux, for instance, has been deliberately devised to isolate officials from the electoral process, or from the demands of 'special interests', for example, thus institutionalizing the very 'unresponsiveness' which so many enthusiasts decry. And, it has been so organized to serve a positive political purpose - to help preserve a modicum of stability, consistency, and continuity, and institutional memory in the face of the vagaries and experimental enthusiasms of partisan politicians, for instance. In this specific and limited sense, the bureaucratic ethos is a conservative one, or better, a conservational one. Bureaucratic practices, that is, formal organization, in public administration can be seen to provide some of the important 'conservation standards' appropriate to the political management of the state, including the management of 'change' within the state.

In the private sector, the need for formality as an organizational ideal is no less important. As we have shown, Wilfred Brown warned of the dangers associated with adopting an informal stance in relation to organizational matters. This is a lesson worth repeating, not least in our time where we fetishize "start-ups, disruptors, and rebels", and where nobody "wants to be an Organization Man” (Brooks, 2015, p. 115). This current anti-formal mindset "has contributed to institutional decay", because, as "the editor Tina Brown has put it, if everybody is told to think outside the box, you've got to expect that the boxes themselves will begin to deteriorate” (ibid.). In conjunction with three decades of deregulation, market romanticism, and idealization of entrepreneurship, this 'thinking out of the box'-mentality has made it abundantly clear that there are significant practical costs associated with a 'fear of the formal'. The results are not only detectable in the proliferation of dysfunctional, economically informed management models that have infiltrated organizational life and created considerable political, social, and economic chaos (Ghoshal, 2005; Dobbin and Jung, 2010; Davis, 2011; Styhre, 2015). It is also visible in the increasing public suspicion toward management as such, which has led Nohria and Khurana (2008) to propose the necessity of having a 'Hippocratic Oath for managers'. Such an oath should perhaps not merely be seen as an attempt to turn management into a profession, thereby fulfilling an ambition initially set forth in the first half of the twentieth century (Khurana, 2010). It could also be seen as an attempt at finding a 
substitute and a cure for the decline of effective and responsible organization that the fear of the formal has brought with it. Viewed from this perspective, the oath can be seen as an attempt to formalize the duties and responsibilities appropriate for the manager as a specific 'persona', thereby reenacting several principles resonant with formal organization. Whether appropriate or not to solve current problems of organization, the very formulation of such an oath seems to testify to the fact that organization throughout the last couple of decades has become too loose, 'spontaneous' and 'informal', and, as a consequence, dysfunctional. While the institutionalization of a Hippocratic Oath for managers might have some benign effects, our contention here would be that several of the answers needed to solve the problem of 'how to make up good organization?' can be lifted directly off the pages of books of classical organization theory, not least Wilfred Brown's.

Turning from the necessity of formality for public and private organizations to some of the theoretical implications associated with the prevailing 'fear of the formal', we'll here end by indicating a couple of interrelated problems. First, as we have seen, a whole range of theorists have, from different points of departure, criticized formal organization for being repressive, authoritarian, favoring a management perspective, lacking spontaneity, imprisoning humans, and a range of other ills. In the process of making such critiques, scholars have started from a range of premises antithetical towards formal organization. Whether it was 'self-actualization', 'individually held norms and beliefs', 'spontaneity', 'informality', ‘excess', 'otherness', 'resistance', or some other notion, several of the criticisms have been developed by utilizing concepts and ideas initially conceived outside the fields' established cannon, thereby broadening organizational theorizing in new directions and towards new objects. To some extent this can be seen as an expected course for a field that has never been mono-disciplinarily anchored, and furthermore always been characterized by internal critiques and contestations (Westwood and Clegg, 2003, p. 3). The question is, however, which costs the critiques, cumulatively viewed, have had? Should we be optimistic about the future of Organization Theory (Engwall, 1982; March, 2007), or perhaps even celebrate the current state of the field (Lounsbury and Beckman, 2015)?

Although it is certainly true that the field has been growing, measured by various quantitative indicators (Lounsbury and Beckman, 2015), it is our contention that in spite of the fact that several of the novel modes of theorizing have opened up new horizons, they have at the same time eroded the very grounds that legitimized Organization Theory as a distinct mode of intellectual inquiry to begin with. More precisely, in criticizing formal organization, in attempting to start from new premises, no matter whether these were founded on psychological, economic, sociological, or 
philosophical premises, several of the new modes of theorizing have effectively undermined the very key object and concept, that is, formal organization, that allowed Organization Theory to establish itself as a distinct academic field to begin with (Blau \& Scott, 1963; Brown, 1965a, 1965b; Blau, 1968; Barnard, 1968). In this way, 'the fear of the formal' has been incredibly productive theoretically speaking. However, the costs of this has at the same time been the development of a field that has progressively alienated itself from what was its original raison d'être.

The question obviously then becomes whether such a development is tolerable in light of the proliferation of ever new theoretical perspectives? Is it romantic and nostalgic to be suspicious of 'the fear of the formal', and to hold on to the importance of formal organization as the rightful key concept and object of Organization Theory? We don't think so. Instead, we propose that organization scholars overcome their 'fear of the formal', and once again confront what used to be the fields' key concept and object. In doing so, organization scholars might be able to contribute more directly to matters of public importance, rather than battling their peers in competition on theory novelty and 'roi-search' (Alvesson, 2013). In stating this, we follow Gary Wickham's (2012) recent work. Wickham states that the discipline of contemporary sociology increasingly has come to appear as a constellation of different milieus that battle each other by trying to impose their own special conceptual constructs on the discipline as such, rather than addressing 'society', that is, what ought to be, and historically has been, sociology’s key object. As Wickham makes clear, this 'balkanization' undermines the public standing of sociology by decreasing the probability that sociology can contribute with much in relation to pressing political and social problems. This insight, we think, could just as rightly be utilized in relation to Organization Theory. If anything, it might even be more needed here. The reason for this is that not only has Organization Theory been plagued by the same development as that described by Wickham. The field has additionally been characterized by a direct contestation and critique of what used to be its key concept and object, that is, formal organization. 


\section{LITERATURE}

Alvesson, M. (2013) 'Do we have something to say? From re-search to roi-search and back again’, Organization, vol. 20, no. 1, pp. 79-90.

Argyris, C. (1970) Personality and Organization: The Conflict between System and the Individual. New York: Harper Torchbooks.

Arvidsson, A. (2008) "The Ethical Economy of Customer Coproduction”, Journal of Macromarketing, 28(4): 326-338.

Arvidsson, A. (2009) "The Ethical Economy: Towards a Post-Capitalist Theory of Value”, Capital \& Class, 33(1): 13-29.

Barnard, C.. I. (1968). The Functions of the Executive. Cambridge, Massachusetts: Harvard University Press.

Barney, J. and W. Ouchi (eds.) (1986) Organizational Economics. San Francisco: Jossey-Bass Publishers.

Benkler, Y. (2006) The Wealth of Networks: How Social Production Transforms Markets and Freedom. New Haven: Yale University Press.

Blau, P. M. (1968) “Organizations”, in David L Sills (ed.) International Encyclopedia of the Social Sciences, Volume 11. New York: The Macmillan Company.

Blau, P. M. and R. W. Scott (1963) Formal Organizations: A Comparative Approach. London: Routledge \& Kegan Paul.

Boltanski, L. \& Chiapello, E. (2005): The New Spirit of Capitalism, London-New York: Verso.

Brooks, D. (2015) The Road to Character. New York: Random House.

Brown, W. (1965a)'Informal Organization?' in W. Brown \& E. Jaques Glacier Project Papers. London: Heineman Educational Books, pp. 144-62.

Brown, W. (1965b) Exploration in Management. Harmondsworth: Penguin Books.

Brown, W. (1976) “A critique of some current ideas about organization” in J. Gray (ed.) The Glacier Project: concepts and critique. New York: Crane Russak.

Bruns, A. (2009) Blogs, Wikipedia, Second Life, and Beyond: From Production to Produsage. New York: Peter Lang.

Davis, G. F. (2011) Managed by the Markets. Oxford: Oxford University Press.

Denhardt, R. B. (1981) In the Shadow of Organizations. Lawrence: Regents Press of Kansas.

Dobbin, F. and J. Jung (2010) "The Misapplication of Mr. Michael Jensen: How Agency Theory Brought Down the Economy and Why It Might Again”, in Michael Lounsbury and Paul M. Hirsch (eds.) Markets on Trial: The Economic Sociology of the U.S. Financial Crisis: Part B. Bingley: Emerald Group.

Donaldson, L. (1995) American anti-management theories of organization: A critique of paradigm proliferation. Cambridge: Cambridge University Press.

du Gay, P. (2008) 'Max Weber and the Moral Economy of Office', Journal of Cultural Economy 1(2):129-144

du Gay, P. (2013) 'Notes on the conceptual architecture of the New Spirit: Weber and Hirschman’ in P. du Gay \& G. Morgan (eds.) New Spirits of Capitalism? Oxford: Oxford University Press 82-97

du Gay, P. (2015) “Organization (Theory) As A Way Of Life”, Journal of Cultural Economy, 8(1): 399-417.

du Gay, P. \& Vikkelsø, S. (2014) "What makes organization? Organizational theory as a 'practical Science'”, in Oxford Handbook of Sociology, Social Theory and Organization Studies: Contemporary Currents, eds. P. Adler, P. Du Gay, G. Morgan \& M. Reed, Oxford University Press, Oxford. 
Engwall, L. (1982) “Organization Theory: Where are You?”, Omega, 10(2): 125-134.

Ferraro, F., Pfeffer, J. and Sutton, R. I. (2005) "Economics Language and Assumptions: How Theories can Become Self-fulfilling”, Academy of Management Review, 30(1): 8-24.

Ghoshal, S. (2005) "Bad Management Theories are Destroying Good Management Practices”, Academy of Management Learning and Education, 4(1): 75-91.

Gray, J.(1976) Glacier Project: concepts and critique London: Heinemann Educational Publishers

Grey, C. (2010) A Very Short, Fairly Interesting and Reasonably Cheap Book About Studying Organizations, second edition. London: Sage.

Hamel, G. (2006) “The Why, What, and How of Management Innovation”, Harvard Business Review, 84(2): 72-84.

Hamel, G. (2009) “Management 2.0”, Leadership Excellence, 26(11): 5-5.

Hamel, G. (2014) "Bureaucracy Must Die”, Harvard Business Review: https://hbr.org/2014/11/bureaucracy-must-die\# (accessed October 14, 2015).

Hamel, G. \& Breen, B. (2007) The Future of Management. Boston, Massachusetts: Harvard Business School Press.

Hardt, M. and A. Negri (2004) Multitude: War and Democracy in the Age of Empire. New York: The Penguin Press.

Harvey, D. (2013) Rebel Cities: From the Right to the City to the Urban Revolution. London: Verso.

Hayek, F. (1974) “The Pretence of Knowledge”, The American Economic Review, 79(6), pp. 3-7.

Helm, C. and Jones, R. (2010). "Extending the Value Chain - A conceptual framework for managing the governance of co-created brand equity”, Journal of Brand Management, 17(8): 579-589.

Hobbes, T (1991) Leviathan Cambridge: Cambridge University Press

Jackson, N. \& Carter, P. (2009) 'The highways and byways of organization studies: reflections on 30 years of critique', Society and Business Review, vol. 4, no. 2, pp. 133-145.

Jensen, M. C. (1983) “Organization Theory and Methodology”, The Accounting Review, 8(2): 319-337.

Jensen, M. C. and W. H. Meckling (1976) "Theory of the firm: Managerial behavior, agency costs and ownership structure”, Journal of Financial Economics, 3(4): 305-360.

Kafka, F. (2015) Franz Kafka: the office writings. New York: Princeton University Press.

Khun, T.S. (1970) The Structure of Scientific Revolutions ( $2^{\text {nd }}$ edition). Chicago: University of Chicago Press.

Khurana, R. (2010) From Higher Aims to Hired Hands: The Social Transformation of American Business Schools and the Unfulfilled Promise of Management as a Profession. Princeton and Oxford: Princeton University Press.

Kneale, K. (2009) "In Pictures: The 10 Most Influential Business Gurus”, Forbes, http://www.forbes.com/2009/10/13/influential-business-thinkers-leadershipthought-leaders-guru_slide_2.html (accessed, September 2, 2015).

Lazzarato, M. (2004) "From Capital-Labor to Capital-Life”, Ephemera: theory \& politics in organization, 4(3): 187-208.

Likert, R. (1961) New Patterns of Management. New York: McGraw-Hill Book Company, Inc. 
Lopdrup-Hjorth, T. (2013) “Let's Go Outside”: The Value of Co-Creation. PhD Dissertation, Copenhagen Business School.

Lopdrup-Hjorth, T. (2015) "Object and objective lost? Organization-phobia in Organization Theory”, Journal of Cultural Economy, 8(1): 439-461.

Lounsbury, M. and Beckman, C.M. (2015) “Celebrating Organization Theory”, Journal of Management Studies, 52(2): 288-308.

Mant, A. (2007) 'Wilfred Brown and Elliott Jaques: an appreciation of a remarkable partnership' in K. Shepard et al. (eds.) Organization Design, Levels of Work \& Human Capability: Executive Guide Ontario: Global organizational Design Society pp. 417 - 427

March, J. G. (1965) “Introduction”, in James G. March (ed.) Handbook of Organizations. Chicago: Rand McNally \& Company.

March, J.G. (2007) “The Study of Organizations and Organizing Since 1945”, Organization Studies, 28(1): 9-19.

March, J. G. and Herbert Simon (1958) Organizations. New York: John Wiley and Sons.

Maslow, A. (1954) Motivation and Personality. New York: Harper.

Mayo, E. (1975) The Social Problems of an Industrial Civilization. London: Routledge \& Kegan Paul.

Mayo, E. (2003) The Human Problems of an Industrial Civilization. New York: The Macmillan Company.

McGregor, D. (2006) The Human Side of Enterprise. New York: McGraw-Hill.

Morgen, G. (1986) Images of Organization. London: Sage Publications.

Moorhouse, F. (1993) Grand Days. London: Vintage.

Nohria, N. and Khurana, R. "It's Time to Make Management a True Profession.” Harvard Business Review, 86(10): 70-77.

Normann, R and Ramírez, R (1993) "From Value Chain to Value Constellation: Designing Interactive Strategy”, Harvard Business Review, 71(4): 65-77.

O’Reilly T. (2009) Gov 2.0: The Promise Of Innovation. http://www.forbes.com/2009/08/10/government-internet-softwaretechnology-breakthroughs-oreilly.html (accessed July 2015).

Oxford English Dictionary. OED Online version, accessed January 2015 (www.oed.com).

Ramaswamy, V. and F. Gouillart (2010) "Building the Co-Creative Enterprise”, Harvard Business Review, October: 100-109.

Parsons, T. (1956) "Suggestions for a Sociological Approach to the Theory of Organizations - I”, Administrative Science Quarterly 1(1): 63-85.

Perrow, C. (1986) Complex Organizations: A Critical Essay. New York: McGrawHill.

Peters, T. (1992) Liberation Management: Necessary Disorganization for the Nanosecond Nineties. London: Macmillan.

Peters, T. (1994) The Tom Peters Seminar: Crazy Times call for Crazy Organizations. New York: Vintage Books.

Peters, T. and Waterman, R.H. (1982) In Search of Excellence. New York: Harper \& Row.

Prahalad, C. K. and Ramaswamy, V. (2000) “Co-opting Customer Competence”, Harvard Business Review, 78(1): 79-87.

Prahalad, C. K. and Ramaswamy, V. (2003) “The New Frontier of Experience Innovation”, MIT Sloan Management Review, 44(4): 12-18. 
Prahalad, C. K. and Ramaswamy, V. (2004a) "Co-creating Unique Value with Customers", Strategy and Leadership, 32(3): 4-9.

Prahalad, C. K. and Ramaswamy, V. (2004b) The Future of Competition: CoCreating Unique Value with Customers. Boston, Massachusetts: Harvard Business School Press.

Prahalad, C. K. and Ramaswamy, V. (2004c) "Co-Creating Experiences: The Next Practice in Value Creation”, Journal of Interactive Marketing, 18(3): 5-14.

Robé, Jean-Phillipe (2011) “The Legal Structure of the Firm”, Accounting, Economics, and Law, 1(1): 1-86.

Roethlisberger, F. J. and W. J. Dickson (2000) Management and the Worker. Bristol: Thoemmes Press.

Rohr, J. (1998) Public Service, Ethics and Constitutional Practice. Lawrence KS: University of Kansas Press

Schein, E.H. (1992) Organizational Culture and Leadership. San Francisco: JosseyBass.

Schuman, D. (1978) The Ideology of Form: The Influence of Organizations in America. Lexington, Massachusetts: Lexington Books.

Shirky, C. (2008) Here Comes Everybody: The Power of Organizing without Organizations. London: Penguin Books.

Silverman, D. (1968) "Formal Organizations or Industrial Sociology: Towards a Social Action Analysis of Organizations”, Sociology, 2(2): 221-238.

Silverman, D. (1987) The Theory of Organizations: A Sociological Framework. Hants: Gower Publishing Company Limited.

Smith, J.H. (1998) “The Enduring Legacy of Elton Mayo”, Human Relations, 51(3): 221-249.

Stinchcombe, A. (2001) When Formality Works: Authority and Abstraction in Law and Organizations. Chicago: University Of Chicago Press.

Stout, L. (2012) The Shareholder Value Myth: How Putting Shareholders First Harms Investors, Corporations, and the Public. San Francisco: BerrettKoehler Publishers.

Strauss, G. (1969) “Human Relations, 1968 Style”, Industrial Relations, 7(3): 262276.

Styhre, A. (2015) “A managerial revolution in reverse: finance market control of the corporation and the triumph of the agency theory model”, Management \& Organizational History, 10(1): 71-86.

Teece, D. J., G. Pisano and A. Shuen (1997) “Dynamic Capabilities and Strategic Management”, Strategic Management Journal, 18(7): 509-533.

Tvede, L. (2015) The Creative Society: How the Future Can Be Won. London: Lid Publishing.

Vargo, S.L. and Lusch, R.F. (2004) "Evolving To a New Dominant Logic for Marketing”, Journal of Marketing, 68(1): 1-17.

Vargo, Stephen L. and Robert F. Lusch (2010) "From Repeat Patronage to Value Cocreation in Service Ecosystems: A Transcending Conceptualization of Relationship”, Journal of Business Market Management, 4(4): 169-179.

von Hippel, Eric (1986) “Lead Users: A Source of Novel Product Concepts”, Management Science, 32(7): 791-805.

von Hippel, Eric (2006) Democratizing Innovation. Cambridge, Massachusetts: The MIT Press.

Waring, S. P. (1991) Taylorism Transformed: Scientific Management theory since 1945. Chapel Hill: The University of Carolina Press. 
Westwood, R. and S. Clegg (2003) "The Discourse of Organization Studies: Dissensus, Politics, and Paradigms”, in R. Westwood and S. Clegg (eds.) Debating Organization: Point-Counterpoint in Organization Studies. Oxford: Blackwell Publishing.

Wheatley, M. and Kellner-Rogers, M. (1996) "Self-Organization: The Irresistible Future of Organizing”, Strategy and Leadership, 24(4): 18-24.

Whyte, W. H. (2002) The Organization Man. Philadelphia: University of Pennsylvania Press.

Wickham, G. (2012) “The core object ‘society’ and sociology’s public relevance”, Journal of Sociology, 48(4): 427-442.

Williamson, O. (1991) "Economic Institutions: Spontaneous and Intentional Governance”, Journal of Law, Economics and Organization, 7: 159-187. 